Abd El-Aziz S. Fouda*1, Ahmed A. El-Hossiany², Heba M. Ramadan ${ }^{1}$

${ }^{1}$ El-Mansoura University, Department of Chemistry, Faculty of Science, El-Mansoura, Egypt, ${ }^{2}$ Delta Fertilizers Company, Talkha, Egypt

Scientific paper ISSN 0351-9465, E-ISSN 2466-2585 UDC:620.193.8 doi: $10.5937 /$ ZasMat $1704541 \mathrm{~F}$

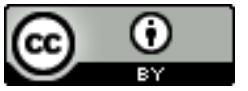

Zastita Materijala 58 (4)

$541-555$ (2017)

\title{
Calotropis procera plant extract as green corrosion inhibitor for 304 stainless steel in hydrochloric acid solution
}

\begin{abstract}
The effect of Calotropis Procera (CP) extract on the corrosion inhibition of 304 stainless steel (SS) in $2 \mathrm{M} \mathrm{HCl}$ was studied using electrochemical (electrochemical impedance spectroscopy (EIS), potentiodynamic polarization (PP) and electrochemical frequency modulation (EFM) and chemical weight loss (WL) methods at $25^{\circ} \mathrm{C}$. The adsorption of the extract on $304 \mathrm{SS}$ surface is consistent with Langmuir adsorption isotherm. The polarization plots revealed that the addition of extract shifts the cathodic and anodic branches towards lower currents. Such shifts indicate that CP extract acts as a mixed-type inhibitor. The thermodynamic parameters of activation and adsorption processes were calculated and discussed. The surface morphology of the 304 SS specimens was evaluating using different techniques.
\end{abstract}

Keywords: Corrosion inhibition, 304 SS, HCl, WL, PP, EIS, EFM.

\section{INTRODUCTION}

Corrosion is the deterioration of essential properties of a material due to reactions with its surroundings. Millions of dollars are lost each year because of corrosion. Much of this loss is due to the corrosion of iron and steel, although many other metals may corrode as well [1]. Stainless steels are important class of metals and are often considered as the main part of modern industry [2]. 304 stainless steel is covered with a highly protective film of chromium oxy-hydroxide [3] and is resistant to corrosion in many aggressive environments. However, it suffers from uniform as well as pitting corrosion under certain drastic conditions [4]. The most important field for applications has being acid pickling, industrial acid cleaning, acid descaling and oil well acidizing. SS type 304 was chosen in this study because of its frequent use and its relatively weak resistance to corrosion, allowing assessing more easily the influence of the environment on corrosion [5]. A large number of plant extract have been studied for inhibiting acid corrosion $[6,7]$.

\footnotetext{
${ }^{\star}$ Corresponding author: Abd El-Aziz S.Fouda

E-mail: asfouda@hotmail.com

Paper received: 24. 09. 2017.

Paper accepted: 15. 10. 2017.

Paper is available on the website:

www.idk.org.rs/journal
}

The objective of this work is to investigate the corrosion inhibition of $\mathrm{SS}$ in $2.0 \mathrm{M} \mathrm{HCl}$ solution using CP extract as a green corrosion inhibitor by using potentiodynamic polarization, electrochemical impedance spectroscopy (EIS), electrochemical frequency modulation (EFM), scanning electron microscopy (SEM), and energy dispersive X-ray (EDX) methods.

\section{EXPERIMENTAL DETAIL}

\subsection{Metal sample and solutions}

The composition of metal sample in weight \% is: $\mathrm{C}$ 0.08; $\mathrm{Mn} 2.0$; Si $0.75 ; \mathrm{P} 0.045 ; \mathrm{S} 0.03, \mathrm{Ni}$ 10.5; Cr 18-20: N 0.1; the rest iron.

Preparation of plant extract: The roots were shade dried at room temperature for 10-15 days and ground into fine powder in a mixer grinder. 200 $g$ powdered sample was extracted with METHANOL $70 \%$ for 48 hrs. The extract was filtered using whatman 1 filter paper (pore size $11 \mu \mathrm{m})$. The solvent removed completely under Rotary vacuum. The dried residues were dissolved in $3 \mathrm{ml}$ of dimethyl sulfoxide (DMSO) and completed to $1000 \mathrm{ml}$ with distilled water and finally stored under refrigeration in glass flasks tapered with screw plastic lid [8]. CP extract contains Tannins steroids, flavonoid, saponin glycosides and some oil of mustard: 


Tannins

The corrosive solution was a $2 \mathrm{M} \mathrm{HCl}$ solution prepared using double distilled water and standardized by standard solution of sodium carbonate. Hydrochloric acid $2 \mathrm{M}$ prepared by dilution of $\mathrm{HCl}(37 \%$, purchased from El-Nasr, Egypt) with double distilled water. The concentration range of the extract was $5-30 \mathrm{ppm}$.

\subsection{Methods used for corrosion techniques}

\subsubsection{Weight loss (WL) technique}

Three parallel stainless steel sheets of $2 \times 2 \times$ $0.2 \mathrm{~cm}$ were abrading with emery paper up to 1200 grit, washed with bidistilled water and acetone. After weighting accurately, the specimens were immersing in $100 \mathrm{ml}$ beaker, which contained $16 \mathrm{ml}$ $2 \mathrm{M} \mathrm{HCl}$ with and without addition of different concentrations of inhibitors at $25 \pm 1^{\circ} \mathrm{C}$. The test specimens suspended by suitable glass hooks at the edge of the basin, and under the surface of the test solution by about $1 \mathrm{~cm}$. All the aggressive acid solutions were open to air. After specified immersion time, the specimens were taken out, washed, dried, and weighed. The average weight loss of the three parallel stainless steel sheets could be obtained. Then the tests were prepared at different temperatures. The inhibition efficiency (\% IE) and the degree of surface coverage $(\theta)$ of investigated inhibitors on the corrosion of SS were calculated from the following equation [9]:

$$
\% I E=\theta \times 100=[(W o-W) / W o] \times 100
$$

where Wo and $W$ are the values of the average weight losses without and with addition of the inhibitor, respectively.

\subsubsection{Potentiodynamic polarization (PP) technique}

Polarization experiments were carried out in a conventional three electrode cell with a platinum counter electrode $\left(1 \mathrm{~cm}^{2}\right)$ and a saturated calomel electrode (SCE) coupled to a fine Luggin capillary as the reference electrode. The working electrode was in the form of a square cut from SS 304 sheet embedded in epoxy resin of polytetrafluoroethylene so that the flat surface area was $1 \times 1 \mathrm{~cm}$. The working electrode abraded with emery papers with grit sizes up to 1200 . Before measurement the electrode immersed in solution at open potential for $30 \mathrm{~min}$. until a steady state reached. The potential started from -500 to $+500 \mathrm{mV}$ vs. open circuit potential (Eop). All experiments were carried out in freshly prepared solutions at room temperature and results were always repeated at least three times to check the reproducibility. The degree of surface coverage $(\theta)$ and inhibition efficiency (\% IE) were calculated from equation (2):

$$
\% \text { IE }=\theta \times 100\left[1-\left(i_{\text {corr }(\text { inh })} / i_{\text {corr(free })}\right)\right] \times 100
$$

where $i_{\text {corr(ree) }}$ and $i_{\text {corr(inh) }}$ are the current densities in the absence and presence of inhibitor, respectively.

\subsubsection{Electrochemical impedance spectroscopy (EIS) technique}

EIS measurements were carried out in a frequency range of $100 \mathrm{kHz}$ to $10 \mathrm{mHz}$ with amplitude of $5 \mathrm{mV}$ peak-to-peak using ac signals at respective corrosion potential. The inhibition efficiency (\% IE) of the inhibitor has been found out from the charge transfer resistance $\left(R_{\mathrm{ct}}\right)$ values using Eq.(3) [10]:

$$
\% I E_{E I S}=\theta \times 100=\left[1-\left(R_{c t} / R_{c t}^{0}\right)\right] \times 100
$$

where $R_{c t}$ and $R_{c t}^{0}$ are the charge transfer resistances in the presence and absence of the extract, respectively. The interfacial double layer capacitance $\left(C_{d l}\right)$ values were obtained [11] by determining the frequencies at which the imaginary component of the impedance is maxima using the following eq. (4):

$$
C_{d l}=Y_{O}\left(\omega_{\max }\right)^{n-1}
$$

where $Y_{0}$ is the CPE coefficient, $\omega_{\max }$ is the frequency at which the imaginary part of impedance $(-Z I)$ has a maximum and $n$ is the CPE exponent (phase shift). 


\subsubsection{Electrochemical Frequency Modulation (EFM) technique}

EFM is a fast and nondestructive experiment technique utilized for the rate of corrosion without prior knowledge of Tafel constants. EFM technique performed using two frequencies $(2.0-5.0 \mathrm{~Hz})$. The choice of the two frequencies based on three arguments [12]. The larger peaks used to calculate the corrosion parameters. The steady-state potential reached after $30 \mathrm{~min}$. The

$\% \mathrm{E}_{\mathrm{EFM}}$ was calculated using the eq. 5 .

$\% \mathrm{IE}_{\mathrm{EFM}}=\theta \times 100=\left[1-\left(\mathrm{i}_{\text {corr }}^{0} / \mathrm{i}_{\text {corr }}\right)\right] \times 100$ (5)

where $i_{\text {corr }}$ and $i_{\text {corr }}^{0}$ are the current of corrosion in $\mathrm{CP}$ extract solution and in $\mathrm{HCl}$, respectively.

\section{2.5. Surface Analysis}

The specimens used for surface morphology examination immersed in $2.0 \mathrm{M} \mathrm{HCl}$ in the absence and presence of $30 \mathrm{ppm}$ of $\mathrm{CP}$ extract at $25^{\circ} \mathrm{C}$ for $3 \mathrm{hr}$. The specimens washed gently with distilled water, then dried carefully and examined. The analysis was performed using scanning electron microscope (JOEL-840, Japan) (SEM), atomic force microscope (AFM) and Attenuated total reflection (ATR) with Fourier transform infrared (FTIR) spectroscopy used for investigation the film formed on the metal surface by Thermo Fisher Nicolet IS10, USA in the spectral range of $400-$ $4000 \mathrm{~cm}^{-1}$.

\section{RESULTS AND DISCUSSION}

\subsection{Weight loss (WL) measurements}

Figure 1 shows plots for the variation of weight loss with time for the corrosion of $S S$ in $2 \mathrm{M} \mathrm{HCl}$ containing various concentrations of $\mathrm{CP}$ at $25^{\circ} \mathrm{C}$. From the plots, it is evident that the weight loss of SS 304 was also found to decrease with increase in the concentration of CP. The weight loss of SS in the blank solution was also found to be higher than those obtained for solutions of $\mathrm{HCl}$ containing various concentrations of $\mathrm{CP}$. This indicates that CP is an inhibitor for the corrosion of SS 304 in solutions of $\mathrm{HCl}$. The data of Table 1 represent the values of corrosion rates of SS 304 and inhibition efficiency of $\mathrm{CP}$ in $\mathrm{HCl}$ solution. The degree of surface coverage $(\theta)$ and inhibition efficiency $(\%$ IE) were calculated using eq. 6 :

$$
\% I E=\theta \times 100=\left[1-\left(C R_{\text {inh }} / C R_{\text {free }}\right)\right] \times 100
$$

where $C R_{\text {inh }}$ and $C R_{\text {free }}$ are the corrosion rates in the presence and absence of inhibitor, respectively. It can be seen that the maximum of $79.1 \%$ inhibition efficiency is achieved at $30 \mathrm{ppm}$ of inhibitor concentration and \% IE increases with increasing the CP concentration [13]. This is mainly due to the co-ordination between the metal and the hetero atom present in $\mathrm{CP}$.

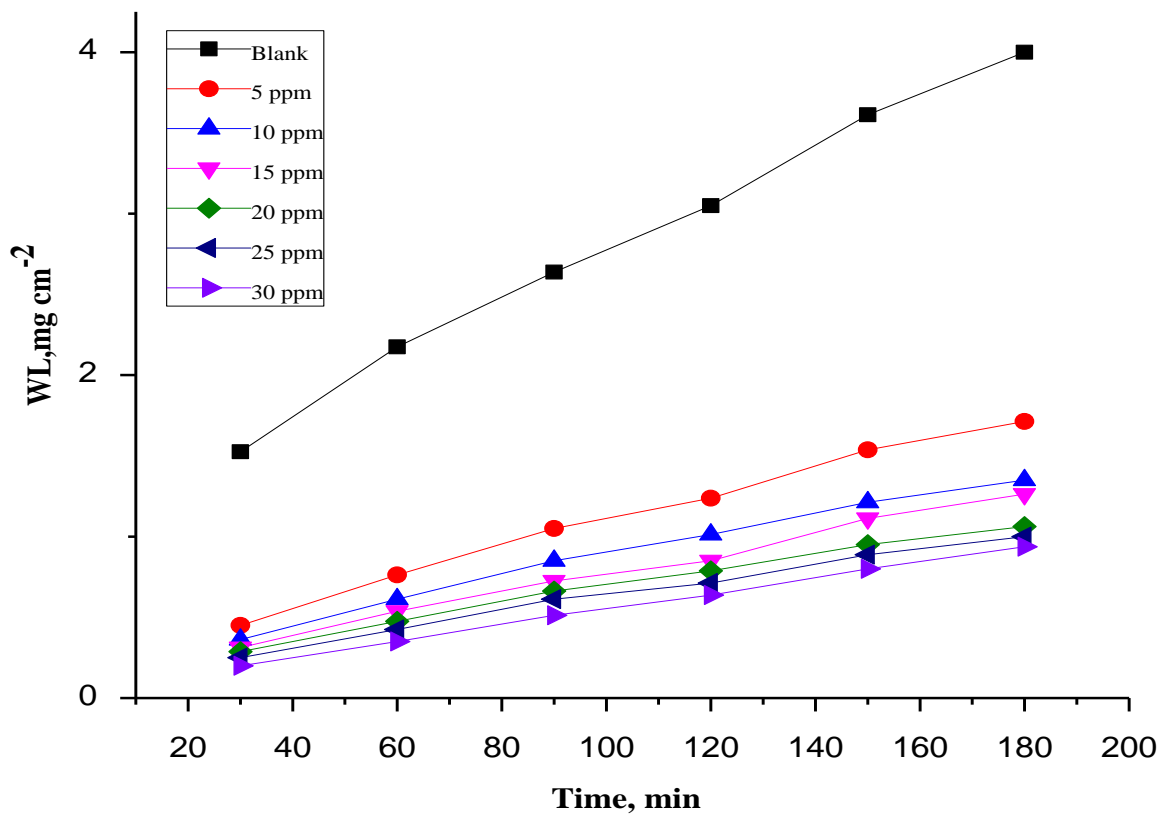

Figure 1: Plots of WL-time for the corrosion of 304 SS without and with various concentrations of CP extract in $2 \mathrm{M} \mathrm{HCl}$ at $25^{\circ} \mathrm{C}$

Slika 1. Krive WL-vreme za koroziju No-304 SS bez i sa različitim koncentracijama CP ekstrakta u $2 \mathrm{M} \mathrm{HCl}$ na $25^{\circ} \mathrm{C}$ 
Table 1: Effect of temperature on \% IE from WL measurements at different temperatures and at 120 min immersion

Tabela 1. Uticaj temperature na \% IE iz WL merenja za različite temperature i za 120 min potapanja

\begin{tabular}{|c|c|c|c|c|}
\hline Temp., ${ }^{\circ} \mathrm{C}$ & [inh], ppm & $\mathrm{k}_{\text {corr }}, \mathrm{mg} \mathrm{cm}^{-2} \mathrm{~min}^{-1}$ & $\theta$ & $\%$ IE \\
\hline \multirow{7}{*}{25} & Blank & 0.025 & - & - \\
\hline & 5 & 0.010 & 0.594 & 59.4 \\
\hline & 10 & 0.008 & 0.668 & 66.8 \\
\hline & 15 & 0.007 & 0.721 & 72.1 \\
\hline & 20 & 0.007 & 0.742 & 74.2 \\
\hline & 25 & 0.006 & 0.766 & 76.6 \\
\hline & 30 & 0.005 & 0.791 & 79.1 \\
\hline \multirow{7}{*}{30} & Blank & 0.029 & ---- & --- \\
\hline & 5 & 0.012 & 0.588 & 58.8 \\
\hline & 10 & 0.010 & 0.656 & 65.6 \\
\hline & 15 & 0.008 & 0.713 & 71.3 \\
\hline & 20 & 0.008 & 0.738 & 73.8 \\
\hline & 25 & 0.007 & 0.763 & 76.3 \\
\hline & 30 & 0.006 & 0.789 & 78.9 \\
\hline \multirow{7}{*}{35} & Blank & 0.040 & $\begin{array}{l}-- \\
\end{array}$ & --- \\
\hline & 5 & 0.021 & 0.486 & 48.6 \\
\hline & 10 & 0.016 & 0.595 & 59.5 \\
\hline & 15 & 0.013 & 0.670 & 67.0 \\
\hline & 20 & 0.012 & 0.691 & 69.1 \\
\hline & 25 & 0.011 & 0.725 & 72.5 \\
\hline & 30 & 0.010 & 0.753 & 75.3 \\
\hline \multirow{7}{*}{40} & Blank & 0.041 & --- & --- \\
\hline & 5 & 0.023 & 0.435 & 43.5 \\
\hline & 10 & 0.018 & 0.559 & 55.9 \\
\hline & 15 & 0.015 & 0.64 .3 & 64.3 \\
\hline & 20 & 0.014 & 0.671 & 67.1 \\
\hline & 25 & 0.012 & 0.701 & 70.1 \\
\hline & 30 & 0.011 & 0.724 & 72.4 \\
\hline \multirow{7}{*}{45} & Blank & 0.062 & --- & --- \\
\hline & 5 & 0.036 & 0.413 & 41.3 \\
\hline & 10 & 0.030 & 0.514 & 51.4 \\
\hline & 15 & 0.025 & 0.600 & 60.0 \\
\hline & 20 & 0.022 & 0.647 & 64.7 \\
\hline & 25 & 0.021 & 0.669 & 66.9 \\
\hline & 30 & 0.019 & 0.686 & 68.6 \\
\hline
\end{tabular}

\subsection{Adsorption isotherms}

Adsorption isotherm values are important to explain the mechanism of corrosion inhibition of organ electrochemical reactions. The most frequently used isotherms are Langmuir isotherm (Fig. 2). Thermodynamic parameters for the adsorption of the extract on 304 SS surface in $2 \mathrm{M}$ $\mathrm{HCl}$ at different temperatures were listed in Table 2. From Table 2 it was found that: the negative values of $\Delta G^{\circ}$ ads reflect that the adsorption of studied $\mathrm{CP}$ on $304 \mathrm{SS}$ in $2 \mathrm{M} \mathrm{HCl}$ solution is spontaneous process [14]. $\Delta G^{\circ}{ }_{\text {ads }}$ values increase (become less negative) with an increase of temperature which indicates the occurrence of exothermic process at which adsorption was unfavorable with increasing reaction temperature as the result of the extract desorption from the 304 SS surface [15]. It is usually accepted that the 
value of $\Delta G^{\circ}$ ads around $-20 \mathrm{~kJ} \mathrm{~mol}^{-1}$ or lower indicates the electrostatic interaction between charged metal surface and charged organic molecules in the bulk of the solution [16]. The negative sign of $\Delta H^{\circ}$ ads revealed that the adsorption of extract molecules is an exothermic process. Generally, an exothermic adsorption process suggests either physisorption or chemisorption while endothermic process is attributed to chemisorptions [17]. Generally, enthalpy values up to $41.9 \mathrm{~kJ} \mathrm{~mol}^{-1}$ are related to the electrostatic interactions between charged molecules and charged metal (physisorption) while those around
$100 \mathrm{~kJ} \mathrm{~mol}^{-1}$ or higher are attributed to chemisorption. In the case of investigated extract, the absolute values of $\Delta S^{\circ}$ ads are relatively low, approaching those typical of physisorption. The values of $\Delta S^{\circ}{ }_{\text {ads }}$ in the presence of investigated extract are large and negative that is accompanied with exothermic adsorption process [18]. The experimental data give good curves fitting for the applied adsorption isotherm as the correlation coefficients $\left(R^{2}\right)$ were in the range 0.980-0.999. $K_{\text {ads }}$ value decreases with the increase of temperature from 25 to $45^{\circ} \mathrm{C}$.

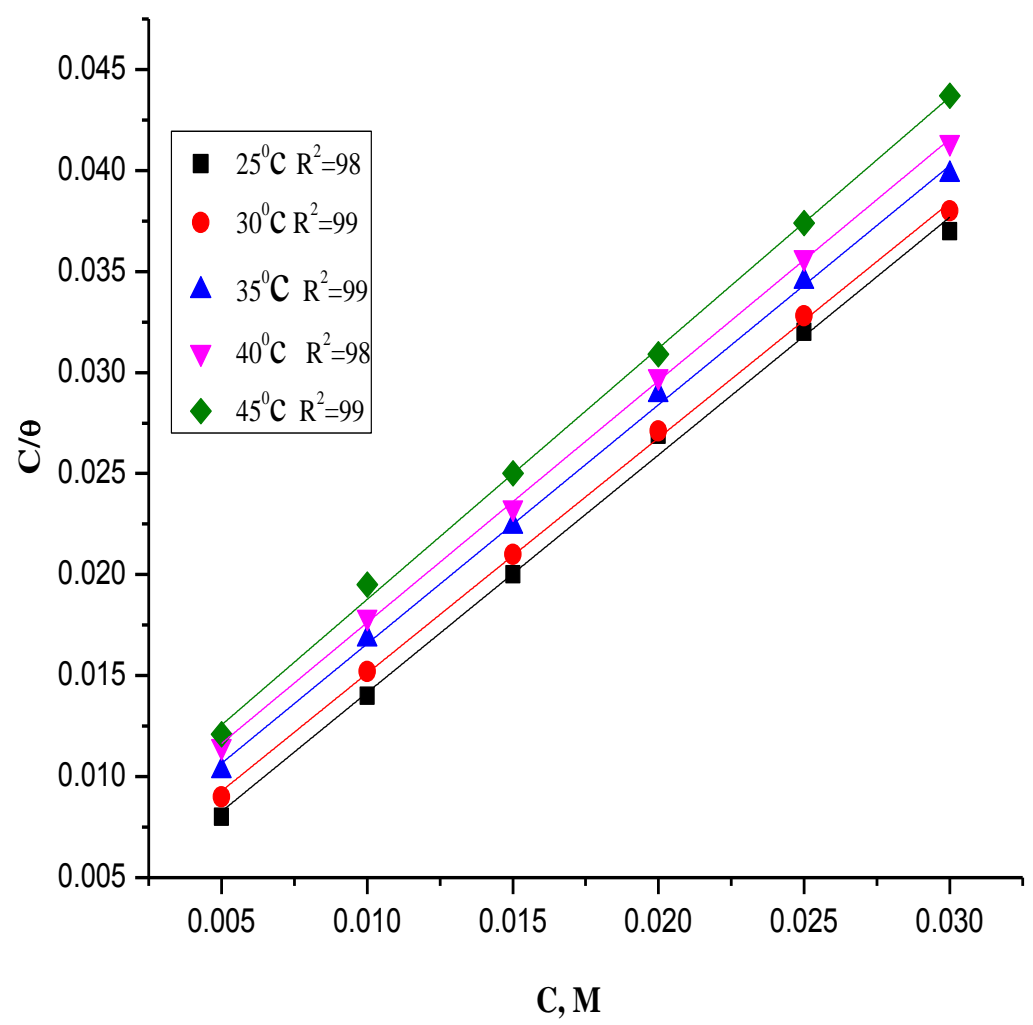

Figure 2. Plots of Langmuir adsorption isotherm as (C/ $(\Theta)$ versus $C$ of $C P$ extract for corrosion of 304 SS in $2 \mathrm{M} \mathrm{HCl}$ solution

Slika 2. Krive Langmuir-ove adsorpcione izoterme kao $(C / \Theta)$ naspram C iz CP ekstrakta za koroziju No304 SS u $2 \mathrm{M} \mathrm{HCl}$ rastvoru

Table 2. Data of $304 \mathrm{SS}$ in $2 \mathrm{M} \mathrm{HCl}$ and with CP extract by Langmuir isotherm at different temperatures

Tabela 2. Podaci za No-304 SS u $2 \mathrm{M} \mathrm{HCl}$ i sa ekstraktom CP iz Langmuirove izoterma na različitim temperaturama

\begin{tabular}{|c|c|c|c|c|c|}
\hline Compound & $\begin{array}{l}T, \\
K\end{array}$ & $\begin{array}{c}k_{\text {ads }} \times 10^{-3} \\
M^{1}\end{array}$ & $\begin{array}{l}-\Delta G_{a d s}^{\circ} \\
k J m o l^{1}\end{array}$ & $\begin{array}{l}-\Delta H_{\text {ads }} \\
k J \mathrm{~mol}^{1}\end{array}$ & $\begin{array}{c}-\Delta S_{a d s}^{\circ} \\
J m o \Gamma^{1} K^{1}\end{array}$ \\
\hline \multirow{5}{*}{ Rumex } & 298 & 418.41 & 24.9 & \multirow{5}{*}{35.2} & 34.4 \\
\hline & 303 & 289.01 & 24.4 & & 35.5 \\
\hline & 308 & 210.97 & 24.1 & & 35.8 \\
\hline & 313 & 176.67 & 23.9 & & 35.9 \\
\hline & 318 & 157.72 & 23.7 & & 36.1 \\
\hline
\end{tabular}




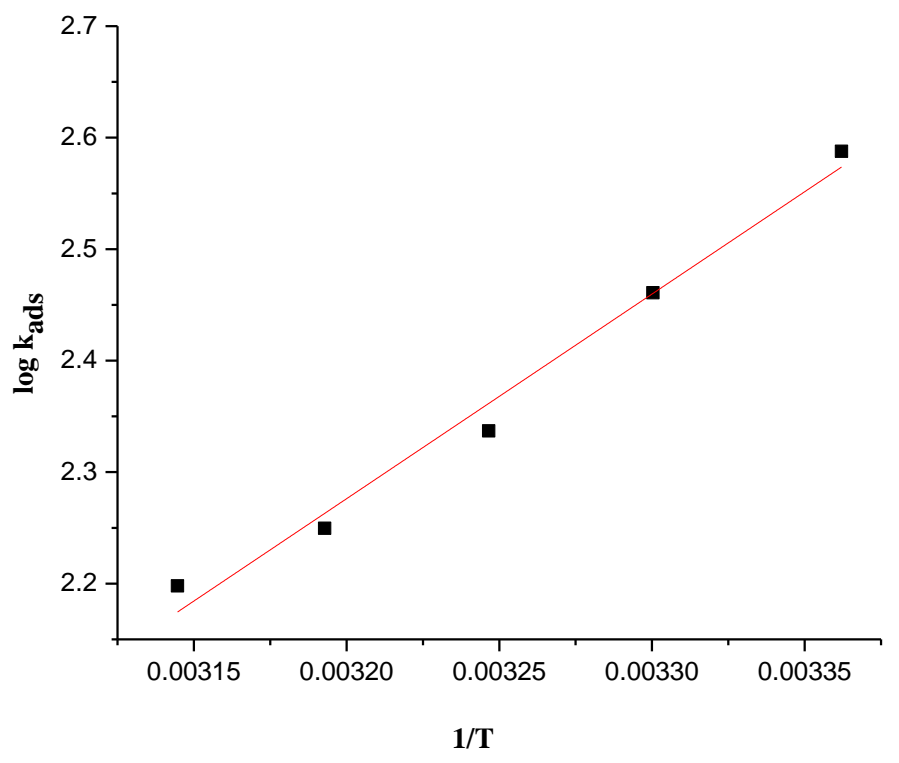

Figure 3. Plot of $\log K_{\text {ads }}$ as a function of the reciprocal temperature for the adsorption of CP extract on $304 \mathrm{SS}$ in $2 \mathrm{M} \mathrm{HCl}$

Slika 3. Kriva log $K_{a d s}$ kao funkcija recipročne temperature za adsorpciju CP ekstrakta na No-304 SS u $2 \mathrm{M} \mathrm{HCl}$

\subsection{Kinetic-thermodynamic corrosion parameters}

The inhibition efficiency (\% IE) for 304 SS corrosion in the presence of various concentrations of the investigated $\mathrm{CP}$ and at different temperatures was calculated and is listed in Table 3.The results of Table 3 shows the variation of $\left(k_{\text {corr }}\right)$ and $\%$ IE with CP concentration at different temperatures. The obtained data revealed that, the $\% \mathrm{IE}$ increases with an increase in CP concentration. This suggested that CP species are adsorbed on the $304 \mathrm{SS} /$ solution interfaces where the adsorbed species mechanically form a protected film on the metal surface which inhibits the action of the corrosion. A close comparison between Table 3 revealed that weight loss of SS increases with increasing temperature indicating that the rate of corrosion of SS increases with increase in temperature. The value of \% IE was decreased with rise in temperature suggesting that physical adsorption mechanism [19]. These results indicate that the adsorption of investigated extract shield the metal surface at room temperature [20]. However it may be shielded from the surface with rise in temperature. It is also clear that corrosion rate of 304 SS in the absence and presence of CP obeys Arrhenius type equation as it increases with raising solution temperature. The dependence of corrosion rate $\left(k_{\text {corr }}\right)$ on the temperature can be expressed by Arrhenius equation 7:

$$
i_{\text {corr }}=A \exp \left(-E_{a}^{*} / R T\right)
$$

where $A$ is the pre-exponential factor and $E_{a}{ }^{*}$ is the apparent activation energy of the corrosion process.

Arrhenius plot obtained for the corrosion of 304 $\mathrm{SS}$ in $2 \mathrm{M} \mathrm{HCl}$ solutions in the presence of different concentrations of $\mathrm{CP}$ is shown in Figure 4. $E_{a}^{*}$ values determined from the slopes of these linear plots are shown in Table 3.The linear regression $\left(R^{2}\right)$ is close to 1 which indicates that the corrosion of $304 \mathrm{SS}$ in $2 \mathrm{M} \mathrm{HCl}$ solutions can be elucidated using the kinetic model. Table 3 showed that the values of $E_{a}{ }^{*}$ for inhibited solution is higher than that for uninhibited solution, suggesting that dissolution of 304 SS is slow in the presence of CP. It is known from Eq. 7 that the higher $E_{a}{ }^{*}$ values lead to the lower corrosion rate. This is due to the formation of a film on the SS surface serving as an energy barrier for the 304 SS corrosion [21]. Enthalpy and entropy of activation $\left(\Delta H^{*}, \Delta S^{*}\right)$ of the corrosion process were calculated from the transition state theory as given from eq. 8 (Table 3$)$ :

$$
k_{\text {corr }}=(R T / N h) \exp \left(\Delta S^{*} / R\right) \exp \left(-\Delta H^{*} / R T\right) \text { (8) }
$$

where $h$ is Planck's constant and $N$ is Avogadro's number. A plot of log $\left(k_{\text {corr }} / T\right)$ vs. $1 / T$ for $S S$ in $2 \mathrm{M}$ $\mathrm{HCl}$ with different concentrations of $\mathrm{CP}$ gives straight lines as shown in Figure 5. Values of $\Delta H^{*}$ are positive. This indicates that the corrosion process is an endothermic one. The entropy of activation $\Delta S^{*}$ is large and negative. This implies that the activated complex represents association rather than dissociation step, indicating that a decrease in disorder takes place, going from reactants to the activated complex [22]. 


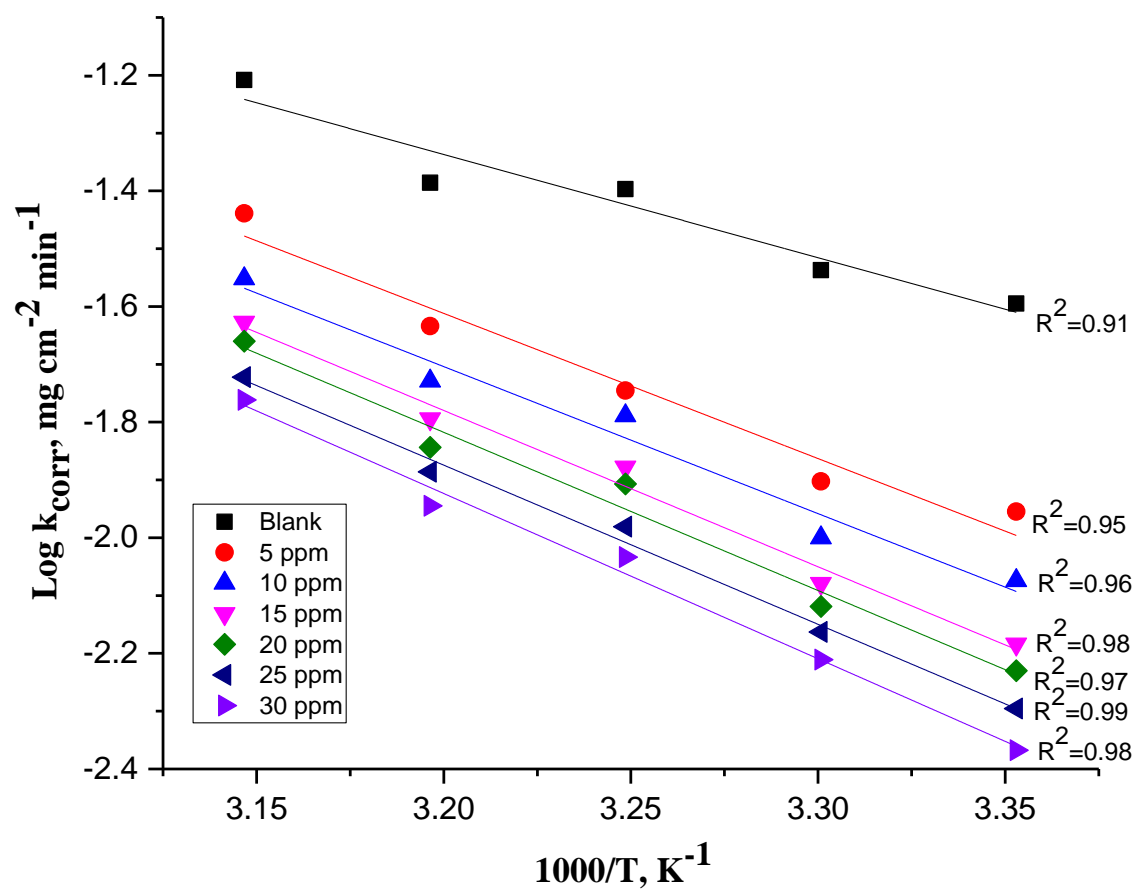

Figure 4. Plots of log $k_{\text {corr }}$ vs. $1 / \mathrm{T}$ for corrosion of 304 SS in $2 \mathrm{M} \mathrm{HCl}$ without and with different concentrations of $C P$ extract

Slika 4. Krive logk $k_{\text {corr }}$ vs 1/T za koroziju No-304 SS u $2 \mathrm{M} \mathrm{HCl} \mathrm{bez} \mathrm{i} \mathrm{sa} \mathrm{razlicitim}$ koncentracijama CP ekstrakta

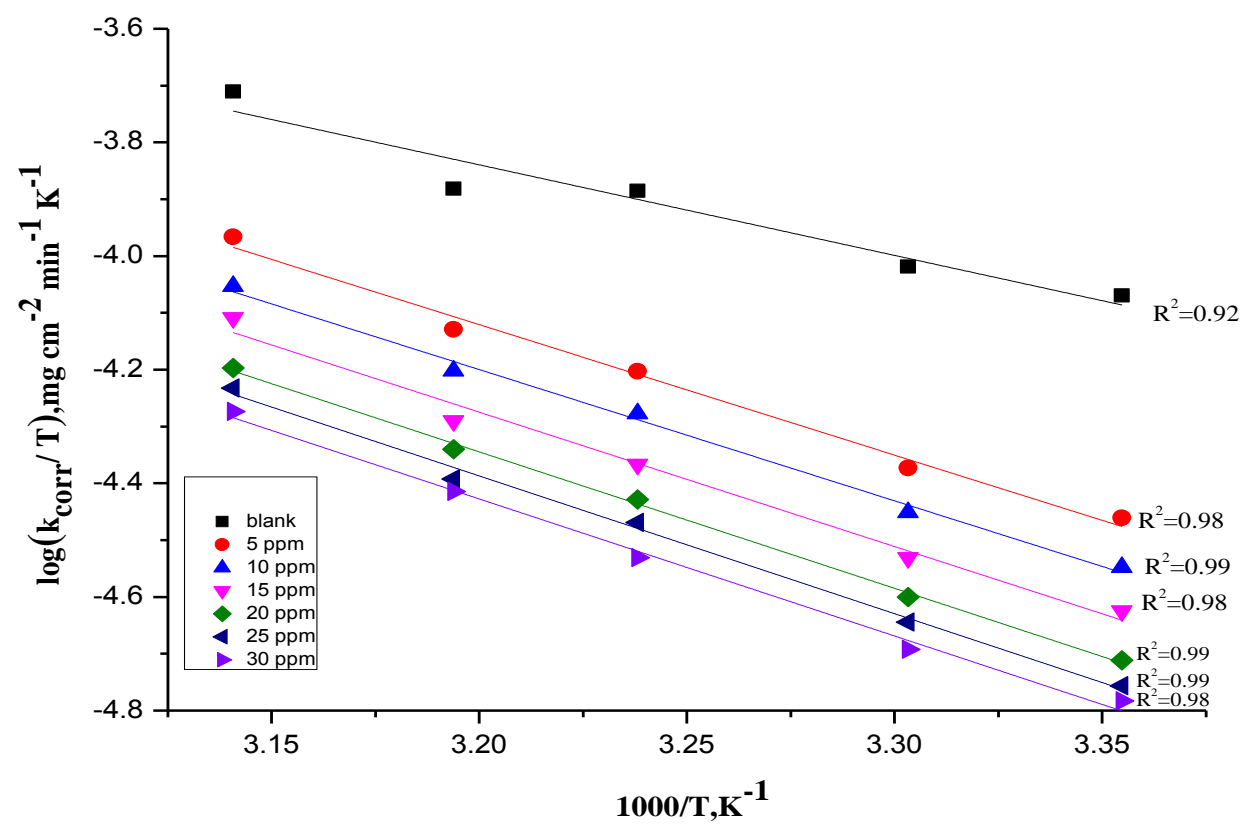

Figure 5: Plots of $\log \left(k_{\text {corr }} / \mathrm{T}\right)$ vs. $1 / \mathrm{T}$ for corrosion of $304 \mathrm{SS}$ in $2 \mathrm{M} \mathrm{HCl}$ without and with different concentrations of CP extract

Slika 5. Krive $\log \left(k_{\text {corr }} / T\right.$ vs $\left.1 / T\right)$ za koroziju No-304 SS u $2 \mathrm{M} \mathrm{HCl} \mathrm{bez} \mathrm{i} \mathrm{sa} \mathrm{različitim}$ koncentracijama CP ekstrakta 
Table 3: Activation parameters for 304 SS corrosion in the absence and presence of various concentrations of $C P$ extract in $2 \mathrm{M} \mathrm{HCl}$

Tabela 3. Parametri aktivacije za koroziju No-304 SS u odsustvu i prisustvu različitih koncentracija $\mathrm{CP}$ ekstrakta u $2 \mathrm{M} \mathrm{HCl}$

\begin{tabular}{|c|c|c|c|}
\hline $\begin{array}{c}\text { Conc, } \\
\text { ppm }\end{array}$ & $\begin{array}{c}E_{a}^{*} \\
\mathrm{~kJ} \mathrm{mo}^{1}\end{array}$ & $\begin{array}{c}\Delta \mathrm{H}^{*} \\
\mathrm{~kJ} \mathrm{moI}^{1}\end{array}$ & $\begin{array}{c}-\Delta \mathrm{S}^{*} \\
\mathrm{~J} \mathrm{mo}^{1} \mathrm{~K}^{1}\end{array}$ \\
\hline Blank & 34.2 & 30.5 & 173.4 \\
\hline 5 & 48.1 & 43.9 & 135.8 \\
\hline 10 & 48.7 & 44.2 & 135.6 \\
\hline 15 & 51.8 & 45.3 & 134.5 \\
\hline 20 & 52.4 & 46.0 & 133.6 \\
\hline 25 & 52.7 & 46.4 & 133.0 \\
\hline 30 & 54.7 & 46.5 & 132.6 \\
\hline
\end{tabular}

\subsection{Electrochemical frequency modulation (EFM) measurements}

EFM is a nondestructive corrosion measurement technique that can directly and quickly determine the corrosion current value without prior knowledge of Tafel slopes, and with only a small polarizing signal. These advantages of EFM technique make it an ideal candidate for online corrosion monitoring [23]. The great strength of the EFM is the causality factors which serve as an internal check on the validity of EFM measurement. The causality factors $C F-2$ and $C F-3$ are calculated from the frequency spectrum of the current responses. Figure 6 shows the frequency spectrum of the current response of pure $304 \mathrm{SS}$ in $2 \mathrm{M} \mathrm{HCl}$. The EFM intermodulation spectrums of pure 304 $\mathrm{SS}$ in $2 \mathrm{M} \mathrm{HCl}$ acid solution containing (5-30 ppm) of the studied inhibitor are shown in Figure 6. The experimental EFM data were treated using two different models: complete diffusion control of the cathodic reaction and the "activation" model. For the latter, a set of three non-linear equations had been solved, assuming that the corrosion potential does not change due to the polarization of the working electrode [24]. The larger peaks were used to calculate the corrosion current density $\left(i_{\text {corr }}\right)$, Tafel slopes $\left(\beta_{c}\right.$ and $\left.\beta_{a}\right)$ and the causality factors (CF-2 and CF-3).These electrochemical parameters were listed in Table 4. The data presented in Table 4 obviously show that, the addition of any one of tested extract at a given concentration to the acidic solution decreases the corrosion current density, indicating that $\mathrm{CP}$ extract inhibit the corrosion of $304 \mathrm{SS}$ in $2 \mathrm{M} \mathrm{HCl}$ through adsorption. The causality factors obtained under different experimental conditions are approximately equal to the theoretical values ( 2 and 3 ) indicating that the measured data are verified and of good quality [25].

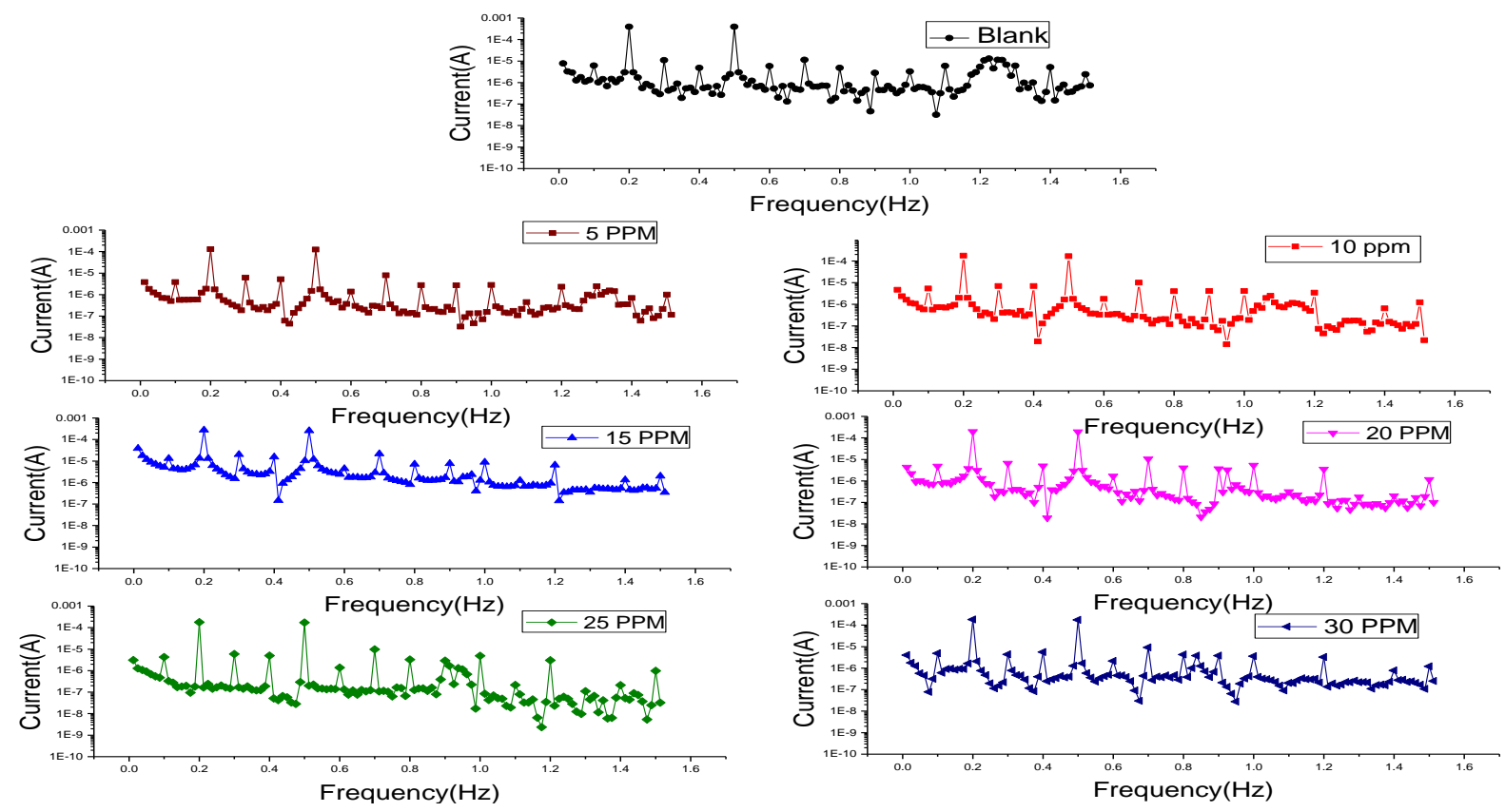

Figure 6. EFM spectra for 304 SS in $2 \mathrm{M} \mathrm{HCl}$ with and without different concentrations of CP extracts

Slika 6. EFM spektri za No-304 SS u $2 \mathrm{M} \mathrm{HCl}$ sa i bez različitih koncentracija CP ekstrakta 
Table 4. Electrochemical kinetic parameters obtained from EFM technique for the corrosion of 304 SS in 2 $\mathrm{M} \mathrm{HCl}$ at different concentrations of $\mathrm{CP}$ extract at $25^{\circ} \mathrm{C}$

Tabela 4. Elektrohemijski kinetički parametri dobijeni EFM tehnikom za koroziju No-304 SS u 2M HCl u različitim koncentracijama $\mathrm{CP}$ ekstrakta na $25^{\circ} \mathrm{C}$

\begin{tabular}{|c|c|c|c|c|c|c|c|c|}
\hline $\begin{array}{c}{[\mathrm{inh}]} \\
\mathrm{ppm}\end{array}$ & $\begin{array}{c}i_{\text {corr, }} \\
\mu A \mathrm{~cm}^{-2}\end{array}$ & $\begin{array}{c}\beta_{c,} \\
m V \operatorname{lec}^{-1}\end{array}$ & $\begin{array}{c}\beta_{a}, \\
m V \operatorname{lec}^{-1}\end{array}$ & $C F-2$ & $C F-3$ & $\begin{array}{c}C . R, \\
m p y\end{array}$ & $\Theta$ & $\%$ IE \\
\hline 0.0 & 627 & 115 & 96 & 1.16 & 2.75 & 286 & - & - \\
\hline 5 & 271 & 78 & 57 & 1.73 & 2.69 & 124 & 0.567 & 56.7 \\
\hline 10 & 243 & 91 & 73 & 1.65 & 2.82 & 111 & 0.619 & 61.9 \\
\hline 15 & 228 & 95 & 75 & 1.58 & 2.86 & 104 & 0.612 & 61.2 \\
\hline 20 & 214 & 85 & 71 & 1.47 & 2.44 & 89 & 0.636 & 63.6 \\
\hline 25 & 196 & 84 & 67 & 1.53 & 2.83 & 85 & 0.687 & 68.7 \\
\hline 30 & 153 & 90 & 69 & 1.77 & 2.41 & 70 & 0.755 & 75.5 \\
\hline
\end{tabular}

\subsection{Electrochemical impedance spectroscopy}

(EIS) method

Nyquist plots of 304 SS in uninhibited and inhibited acid solutions containing different concentrations of CP are present in Figure 7. EIS spectra obtained consists of one depressed capacitive loop. The increased diameter of capacitive loop obtained in $2 \mathrm{M} \mathrm{HCl}$ in presence of CP indicated the inhibition of corrosion of 304 SS. The high frequency capacitive loop may be attributed to the charge transfer reaction. Corrosion kinetic parameters derived from EIS measurements and inhibition efficiencies given in Table 5. Double layer capacitance $\left(C_{d l}\right)$ and charge transfer resistance $\left(R_{c t}\right)$ obtained from EIS measurements as described elsewhere [26]. It is apparent from Table 5 that the impedance of the inhibited system amplified with the addition of the extract and the $C_{d l}$ values decreased. This decrease in $C_{d l}$ results from a decrease in local dielectric constant and/or an increase in the thickness of the double layer, suggested that extract molecules inhibit the SS corrosion by adsorption at the metal/acid interface [27].

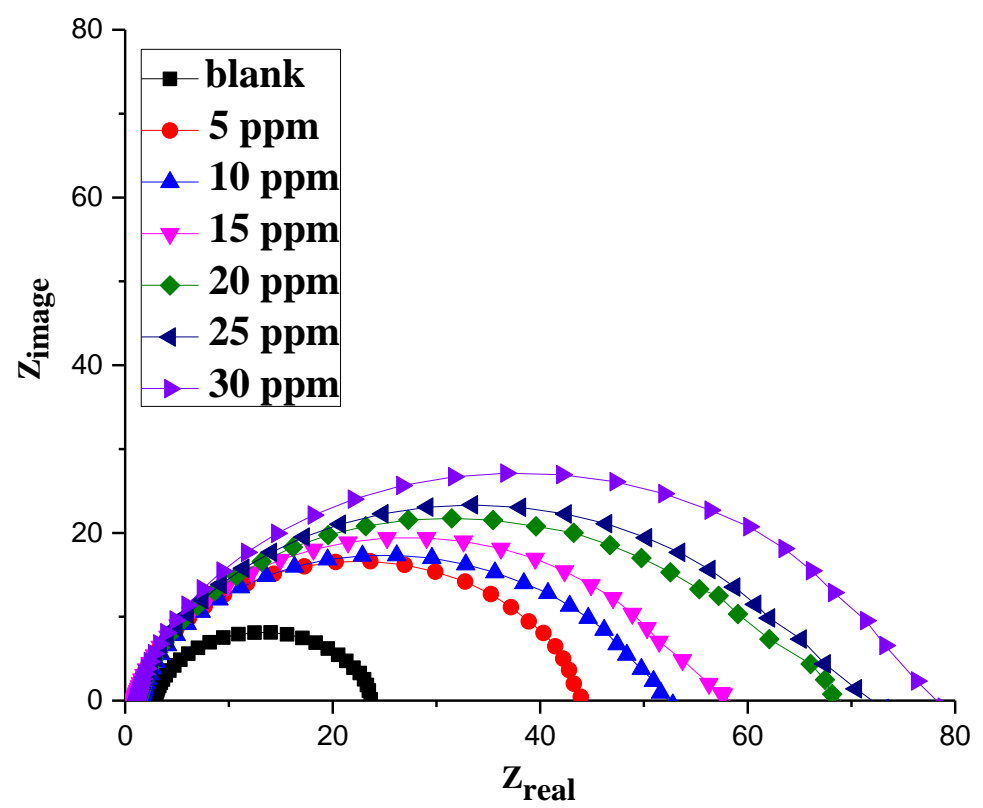

Figure 7. The Nyquist plots for corrosion of 304 SS in $2 \mathrm{M} \mathrm{HCl}$ without and with different concentrations of $\mathrm{CP}$ at $25^{\circ} \mathrm{C}$

Slika 7. Nyquist-ove krive za koroziju No-304 SS u $2 \mathrm{M} \mathrm{HCl}$ bez i sa različitim koncentracijama $\mathrm{CP}$ na $25^{\circ} \mathrm{C}$ 
Table 5. EIS data of 304 SS in $2 \mathrm{M} \mathrm{HCl}$ and with and without different concentrations of CP extract at 25ㄷ

Tabela 5. EIS podaci za No-304 SS u $2 \mathrm{M} \mathrm{HCl}$ sa i bez različitih koncentracija CP ekstrakta na $25^{\circ} \mathrm{C}$

\begin{tabular}{|c|c|c|c|c|}
\hline [inh.], ppm & $R_{c t,} \Omega \mathrm{cm}^{2}$ & $C_{d l,} \mu F_{c m}^{-2}$ & $\theta$ & $\%$ IE \\
\hline 0.0 & 20 & 155 & --- & -- \\
\hline 5 & 42 & 97 & 0.523 & 52.3 \\
\hline 10 & 48 & 152 & 0.583 & 58.3 \\
\hline 15 & 50 & 99 & 0.60 & 60.0 \\
\hline 20 & 58 & 190 & 0.656 & 65.6 \\
\hline 25 & 62 & 112 & 0.677 & 67.7 \\
\hline 30 & 66 & 98 & 0.697 & 69.7 \\
\hline
\end{tabular}

\subsection{Potentiodynamic polarization (PP) measurements}

Figure 8 presents the results of the effect of $\mathrm{CP}$ extract on the cathodic and anodic polarization curves of $304 \mathrm{SS}$ in $2 \mathrm{M} \mathrm{HCl}$. It could be observed that both the cathodic and anodic reactions were suppressed with the addition of investigated extract, which suggested that $\mathrm{CP}$ extract reduced anodic dissolution and also retarded the hydrogen evolution reaction. Electrochemical corrosion kinetics parameters, i.e. corrosion potential $\left(E_{c o r r}\right)$, cathodic and anodic Tafel slopes $\left(\beta_{a}, \beta_{c}\right)$ and corrosion current density $\left(i_{\text {corr }}\right)$ obtained from the extrapolation of the polarization curves, were given in Table 6. The parallel cathodic Tafel curves in Figure 8 suggested that the hydrogen evolution is activation-controlled and the reduction mechanism is not affected by the presence of the inhibitor.

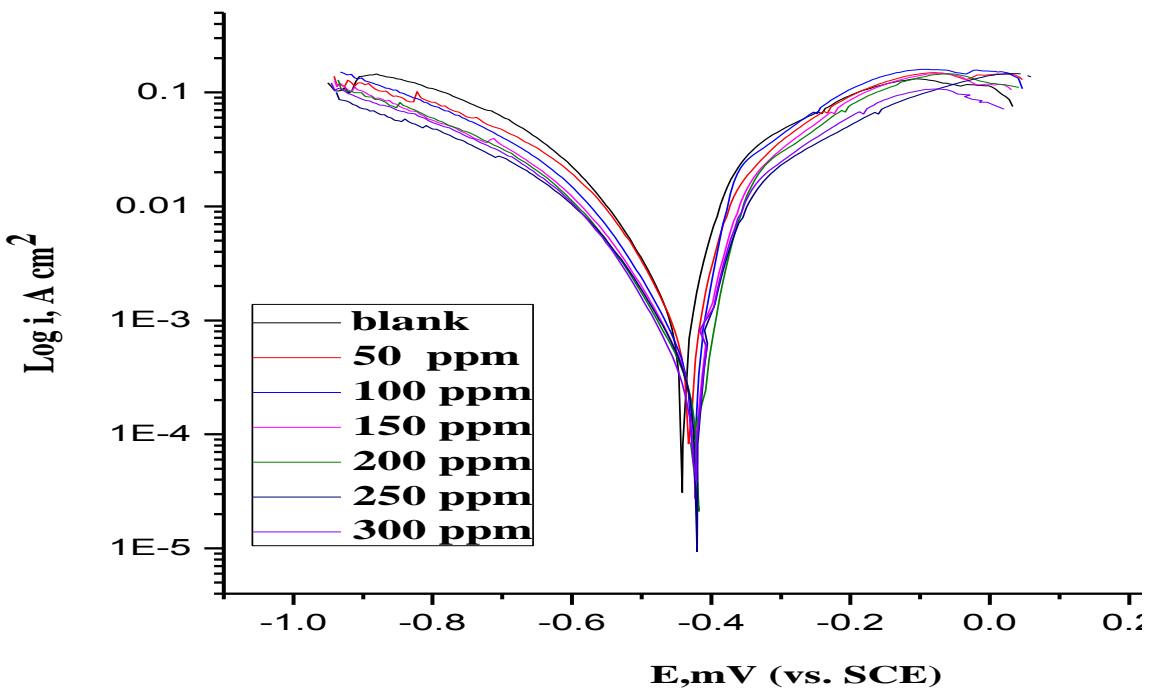

Fig. 8. PP curves for the dissolution of 304 SS in $2 \mathrm{M} \mathrm{HCl}$ with and without different concentrations of $\mathrm{CP}$ extract at $25^{\circ} \mathrm{C}$

Slika 8. PP krive za rastvaranje No-304 SS u $2 \mathrm{M} \mathrm{HCl} \mathrm{sa} \mathrm{i} \mathrm{bez} \mathrm{različitih}$ koncentracija $\mathrm{CP}$ ekstrakta na $25^{\circ} \mathrm{C}$

The region between linear part of cathodic and anodic branch of polarization curves becomes wider as the inhibitor is added to the acid solution. Similar results were found in the literature [28]. The values of $\beta_{a}$ and $\beta_{c}$ changed slightly with increasing inhibitor concentration indicated the influence of these compounds on the kinetics of metal dissolution and of hydrogen evolution. As it can be seen from Table 6 , the studied inhibitor reduced both anodic and cathodic currents with a slight shift in corrosion potential $(21 \mathrm{mV})$. The results obtained from Tafel polarization showed good agreement with the results obtained from WL method. 
Table 6. Corrosion parameters of 304 SS in $2 \mathrm{M} \mathrm{HCl}$ obtained from PP containing various concentrations of $\mathrm{CP}$ at $25^{\circ} \mathrm{C}$

Tabela 6. Parametri korozije No-304 SS u 2M HCl dobijeni iz PP koji sadrže različite koncentracije CP na $25^{\circ} \mathrm{C}$

\begin{tabular}{|c|c|c|c|c|c|c|c|}
\hline $\begin{array}{c}{[\text { inh.] }} \\
\mathrm{ppm}\end{array}$ & $\begin{array}{c}-E_{\text {corr, }} m V \\
(v s . S C E)\end{array}$ & $\begin{array}{c}i_{\text {corr, }} \\
\mu A \mathrm{~cm}^{-2}\end{array}$ & $\begin{array}{c}\beta_{c} \\
m V d e c^{-1}\end{array}$ & $\begin{array}{c}\beta_{a} \\
m V d e c^{-1}\end{array}$ & $\begin{array}{c}C . R, \\
m p y\end{array}$ & $\theta$ & $\%$ IE \\
\hline 0 & 441 & 1020 & 109 & 52 & 466 & $-\cdots$ & $-\cdots$ \\
\hline 5 & 431 & 634 & 98 & 44 & 289 & 0.378 & 37.8 \\
\hline 10 & 426 & 511 & 116 & 40 & 233 & 0.499 & 49.9 \\
\hline 15 & 422 & 459 & 122 & 49 & 209 & 0.550 & 55.0 \\
\hline 20 & 421 & 438 & 107 & 41 & 200 & 0.570 & 57.0 \\
\hline 25 & 421 & 357 & 114 & 43 & 163 & 0.650 & 65.0 \\
\hline 30 & 420 & 291 & 107 & 42 & 132 & 0.715 & 71.5 \\
\hline
\end{tabular}

\subsection{Surface characterization}

\subsubsection{Scanning electron microscope (SEM) test}

Figure 9 represents the micrograph obtained for 304 SS samples in presence and in absence of $\mathrm{CP}$ extract after exposure for $24 \mathrm{~h}$ immersion. It is clear that 304 SS surfaces suffer from severe in the solution, the morphology of 304 SS surfaces is quite different from the previous one, and the specimen surfaces were smoother. We noted the formation of a film which is distributed in a random

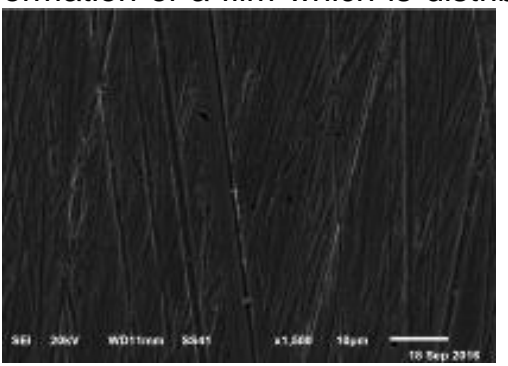

a)

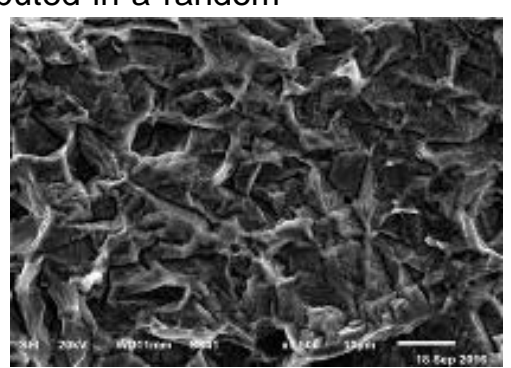

b) way on the whole surface of the 304SS. This may be interpreted as due to the adsorption of the CP extract on the 304 SS surface incorporating into the passive film in order to block the active site present on the 304 SS surface. Or due to the involvement of inhibitor molecules in the interaction with the reaction sites of 304 SS surface, resulting in a decrease in the contact between SS type 304 and the aggressive medium and sequentially exhibited excellent inhibition effect [29].

Figure 9 a-c: SEM micrographs of 304 SS surface (a) free surface of 304 SS, (b) after 1 day of immersion in $2 \mathrm{M} \mathrm{HCl}$ and (c) after 1 day of immersion in $2 \mathrm{M} \mathrm{HCl}+30 \mathrm{ppm}$ of $\mathrm{CP}$

Slika 9 a-c. SEM mikrografija na površini No-304 SS (a) čista površina, (b) nakon 1 dana uranjanja u $2 M$ $\mathrm{HCl}$ i (c) nakon 1 dan uranjanja u $2 \mathrm{M} \mathrm{HCl}+30 \mathrm{ppm} \mathrm{CP}$

\subsection{AFM analysis}

The surface roughness of the deposits obtained from the baths without and with CP (30 ppm) was examined by high-resolution AFM; the results are shown in Figs.10-12, respectively. For the deposits obtained from the baths without and with $\mathrm{CP}$, the surface roughness $\left(R_{\max }\right)$ values were $501.9 \mathrm{~nm}, 40.02 \mathrm{~nm}$ and $241.07 \mathrm{~nm}$, respectively. The $R_{\max }$ value decreased with the addition of CP to the bath, indicating that the coating deposited in the presence of CP exhibited a smooth and shiny surface [30]. Our analysis revealed that a deposit with a smooth surface, which may impart high corrosion resistance, was obtained when CP (30 ppm) was added to the electrolyte.

\subsubsection{ATR-FTIR analysis}

Figure 13 presents FT-IR spectra. The broad peak between $3300 \mathrm{~cm}-1$ and $3500 \mathrm{~cm}^{-1}$ corresponding to $\mathrm{OH}$ vibrations is the highest [31]. Those observations are consistent with the previous assumptions. Moreover, the peaks that originated from $-\mathrm{CH}_{3}$ asymmetric stretching (2957 $\left.\mathrm{cm}^{-1}\right),\left(1634 \mathrm{~cm}^{-1}\right)$, vibrations are the highest for the coatings deposited from aqueous solutions [32]. Bands at $1267 \mathrm{~cm}^{-1}$ and $1053 \mathrm{~cm}^{-1}$ are assigned to the -CN (symmetric bending) and -CO (asymmetric stretching) vibrations, respectively [33]. Intensities of those peaks confirm that there is a welldeveloped, cross-linked structure in the case of coatings deposited from aqueous solutions, which 
contain uncondensed and hydrolyzed groups within the structure [34]. The results presented in the
Figure 13 suggest that CP sample coating is much thicker.
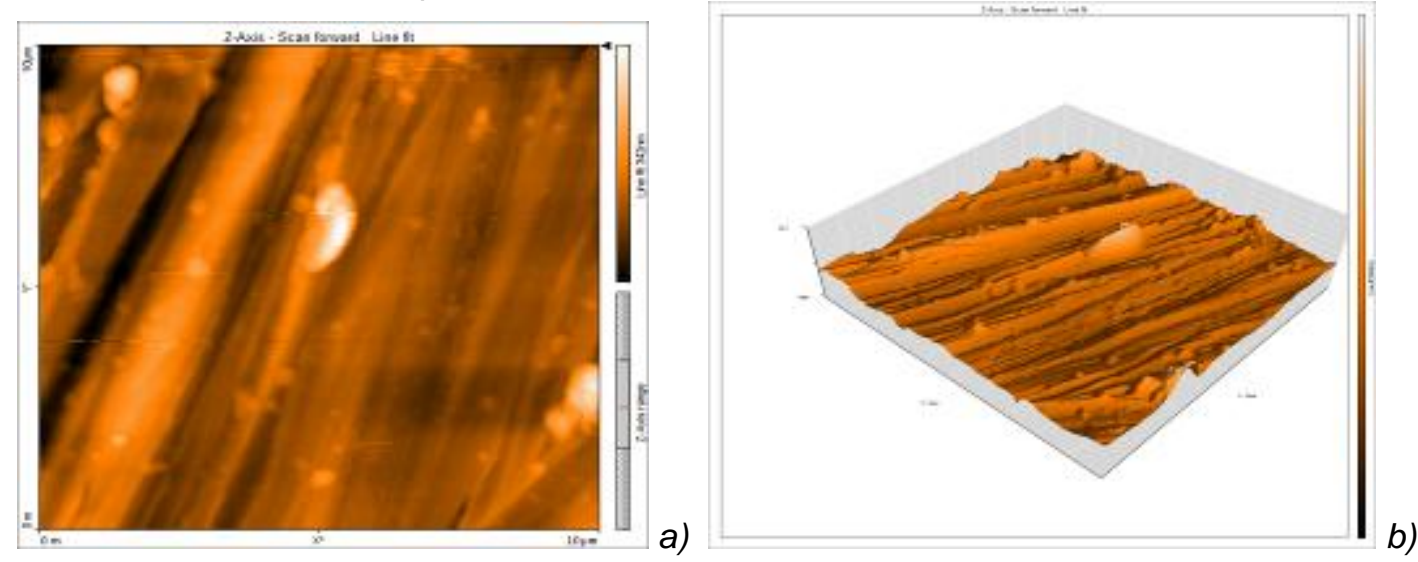

Figure 10. 2D (a) and 3D (b) AFM images of 304 SS free surface

Slika 10. 2D (a) i 3D (b) AFM slike na čistoj površini No-304 SS
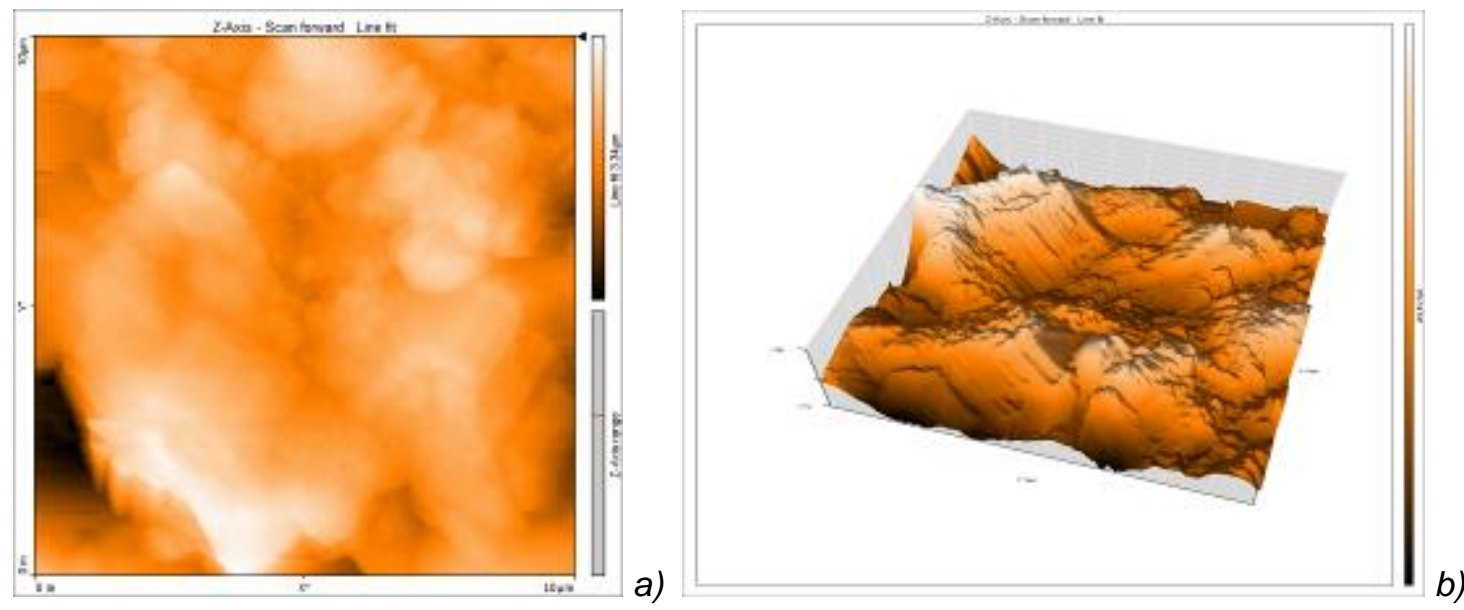

Figure 11. 2D (a) and $3 D$ (b) AFM images of 304 SS electrodeposits in $2 \mathrm{M} \mathrm{HCl}$ Slika 11. 2D (a) i 3D (b) AFM slike No-304 SS elektrodepozita u $2 \mathrm{M} \mathrm{HCl}$
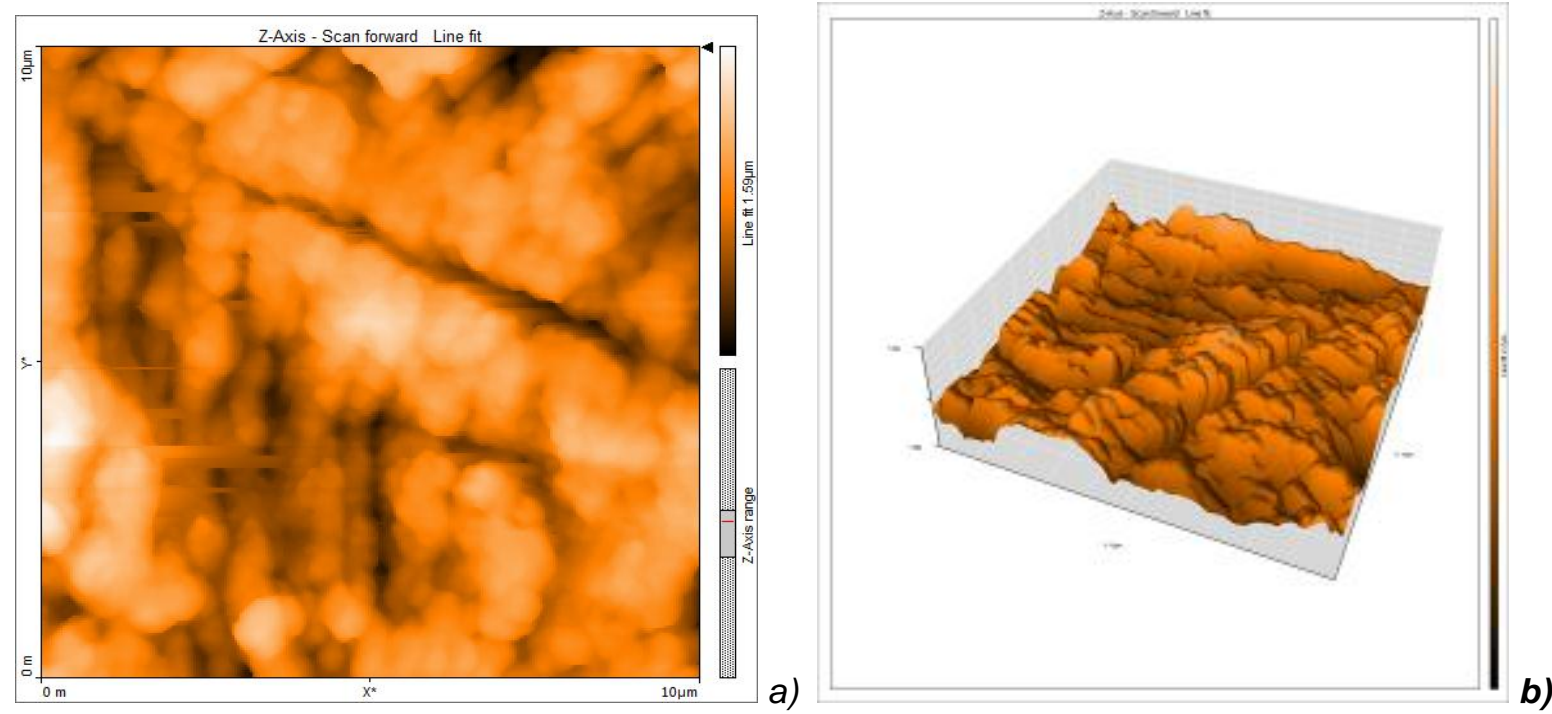

Figue 12. 2D (a) and 3D (b) AFM images of SS electrodeposits in presence of $C P$ Slika 12. 2D (a) i 3D (b) AFM slike SS elektrodepozita u prisustvu $C P$ 


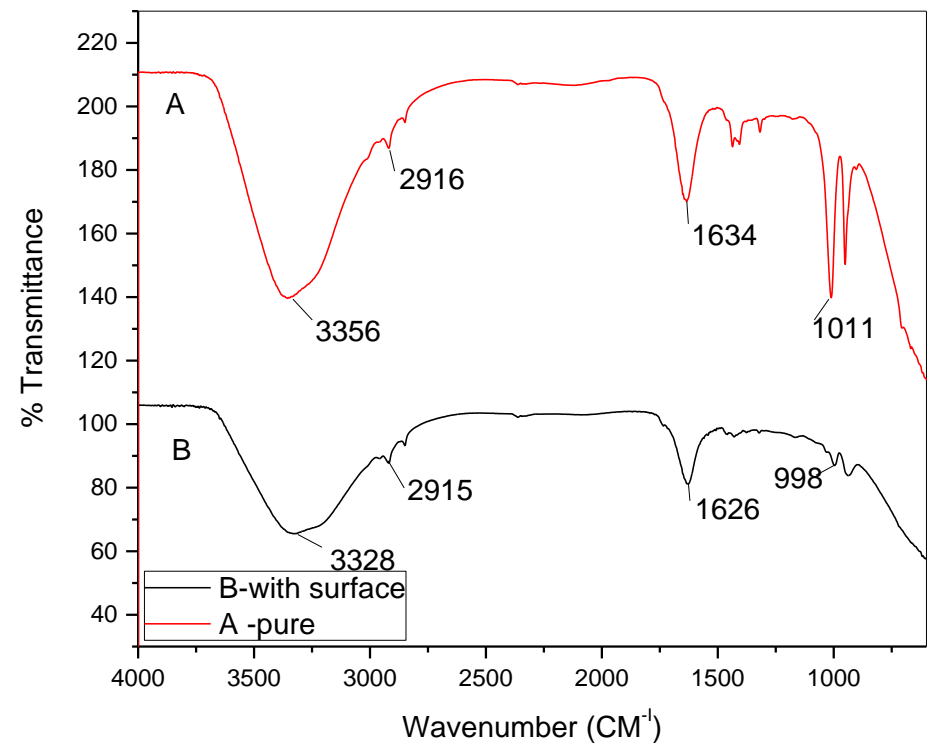

Figure 13. ATR- FTIR finger print spectra of CP solution (30 ppm) (B) and adsorbed layer of CP on 304 SS surface $(A)$

Slika 13. ATR-FTIR spektar CP rastvora (30 ppm) (B) i adsorbovanog sloja CP na površini nerđajućeg čelika 304 SS (A)

\subsection{Corrosion inhibition mechanism}

In acidic solutions, transition of the metal/ solution interface is attributed to the adsorption of the inhibitor molecules at the metal/solution interface, forming a defensive film. The rate of adsorption is typically fast, and thus, the reactive metal surface is protected from the corrosive solutions. Inhibition of the $304 \mathrm{SS}$ in $2 \mathrm{M} \mathrm{HCl}$ by the investigated extract as indicated by WL, PP, EIS, EFM and other methods were found to depend on the number of adsorption sites in the molecules that present in $\mathrm{CP}$ extract and their charge densities, molecular size and stability of these additives in acidic solution. The observed corrosion data in presence of this extract, namely: i) the decrease of corrosion rate and corrosion current with increase in concentration of the extract ii) linear variation of weight loss with time and iii) the shift in Tafel lines to higher potential regions. The decrease in corrosion inhibition with increasing temperature indicates that desorption of the adsorbed extract molecules takes place. The IE was shown to depend on the number of adsorption active centers in the molecules and their charge densities. Adsorption on SS surface is assumed to take place mainly through the active centers attached to the inhibitor and would depend on their charge density. It was concluded that the mode of adsorption depends on the affinity of the metal towards the m-electron clouds of the ring system. Metals such as $\mathrm{Fe}$ and $\mathrm{Cr}$, which have a greater affinity towards aromatic moieties, were found to adsorb benzene rings in a flat orientation and the functional groups have coordinated with 304 SS formed on the metal.

\section{CONCLUSIONS}

Based on the above results of this study, the following conclusions can be drawn:

The studied plant extract (CP) is an effective inhibitor for corrosion of $304 \mathrm{SS}$ in $2 \mathrm{M} \mathrm{HCl}$ solution.

The adsorption of extract depends on its concentration, temperatures and the natural of the extract and metal. Reasonably good agreement was observed between the values obtained by the weight loss and electrochemical measurements. Results obtained from potentiodynamic polarization indicated that CP extract is mixed-type inhibitor. The adsorption of CP onto 304 SS surface follows the Langmuir adsorption isotherm model, and is due to the formation of a physical adsorbed film on the metal surface. The SEM images of the 304 SS samples showed that the metal was protected in the presence of the extract.

\section{REFERENCE}

[1] S. Kadry (2008) Corrosion analysis of stainless steel, Eur. J. Scientific Res., 22, 508-516.

[2] H.S. Khatak, R. Baldev (2002) Corrosion of Austenitic Stainless Steels: Mechanism, Mitigation and Monitoring. ASM International. Narosa Publishing House. $1^{\text {st }}$ ed. 
[3] G.Okamoto (1973) Passive film of $18-8$ stainless steel structure and its function, Corros. Sci., 13,471489.

[4] A.J. Sedriks (1979) Corrosion of Stainless Steel, Wiley-Interscience, New York.

[5] A.J.Szypowski (2002) Impedance study of imidazoline inhibitors against hydrogen sulphide corrosion of steel, , Br. Corros. J. 37, 141- 146.

[6] S.L. Granese, B.M. Rosales, C.Ovideo, J.O.Zerbino (1992) The inhibition action of heterocyclic nitrogen organic compounds on $\mathrm{Fe}$ and steel in $\mathrm{HCl}$ media, Corros.Sci., 33, 1439-1453.

[7] A.S. Fouda, M. Morsi, H.A.Mosallim (2016) Capsicum extract as green corrosion extract for carbon steel in hydrochloric acid solutions, Zastita materijala, 57 (1), 33 - 45.

[8] M. Abdulwahab , A.Kasim , O. S. I. Fayomi, F. Asuke , A. P. I. Popoola (2012) Inhibitive effect of Arachis hypogeae on the corrosion of mild steel in sulphuric acid solution, J. Mater. Environ. Sci., 3 (6), 1177-1182.

[9] J.D.Talati, R.M.Modi (1986) study on grindability of inconel 718 by cbn wheels, Trans.SEAST, 11, 925-935.

[10] F.Bentiss, M.Lagrenee, M.Traisnel, J.C.Hornez (1999) The corrosion inhibition of mild steel in acidic media by a new triazole derivative, Corros. Sci., 41, 789-803.

[11] C.H.Hsu, F.Mansfeld (2001) Concerning the Conversion of the Constant Phase Element Parameter $Y_{0}$ into a Capacitance, Corrosion, 57, 747-748.

[12] K. Khaled (2009) Evaluation of electrochemical frequency modulation as a new technique for monitoring corrosion and corrosion inhibition of carbon steel in perchloric acid using hydrazine carbodithioic acid derivatives. J Appl Electrochem, 39, 429-438.

[13] A.Zaafarany, M. Abdallah (2010) Ethoxylated Fatty Amide as Corrosion Inhibitors for Carbon Steel in Hydrochloric Acid Solution, Int.J. Electrochem. Sci., 5, 18-28.

[14] L.Tang, X.Lie, Y.Si, G.Mu, G.Liu (2006) The synergistic inhibition between 8-hydroxyquinoline and chloride ion for the corrosion of cold rolled steel in $0.5 \mathrm{M}$ sulfuric acid, Mater. Chem. Phys., 95, 2938.

[15] L.Tang, G.Murad, G.Liu (2003) The effect of neutral red on the corrosion inhibition of cold rolled steel in 1.0 M hydrochloric acid, Corros. Sci., 45, 2251 2262.

[16] I.N.Putilova, S.A.Blazin, U.P.Baranik (1960) Metal Corrosion Inhibitors, Pergamon Press, New York, NY, USA.

[17] A. K. Singh, M.A.Quraishi Piroxicam (2010) A novel corrosion inhibitor for mild steel corrosion in $\mathrm{HCl}$ acid solution, J. Mater. Environ. Sci., 1(2), 101-110.

[18] A.A.El-Awady, B.Abd El-Nabey, S.G.Aziz (1992) Kinetic Thermodynamic and Adsorption Isotherms Analyses for the Inhibition of the Acid Corrosion of Steel by Cyclic and Open Chain Amines, Electrochem. Soc., 139, 2149-2154.
[19] P.O.Ameh, N.O.Eddy (2013) A review on the assessment of polymeric materials used as corrosion inhibitor of metals and alloys, Res. Chem. Intermediates, 45, 1- 9.

[20] A.S.Fouda, M.A. Elmorsi (2016 ) Fayed \&I.A. El said, Oxazole derivatives as corrosion inhibitors for $316 \mathrm{~L}$ stainless steel in sulfamic acid solutions, Journal Desalination and Water Treatment, 57(10), 4371-4385.

[21] A.S.Fouda, A.A.Al-Sarawy, E.E.El-Katori (2006) Pyrazolone derivatives as corrosion inhibitors for Csteel in hydrochloric acid solution, Desalination, 201, 1-13.

[22] G,Gece (2008) The use of quantum chemical methods in corrosion inhibitor studies, Corros. Sci., 50, 2981-2992.

[23] G. A. Caigman, S. K. Metcalf, E. M. Holt (2000) Thiophene substituted dihydropyridines, J.Chem. Cryst., 30, 415- 422.

[24] N.Shwetha, P. Rao ( 2017) Sinapis alba as an AntiRusting Agent for Corrosion of Stainless Steel in Hydrochloric Acid Medium, Surface Engineering and Applied Electrochemistry, 53( 3), 265-273.

[25] R.A.Prabhu, T.V.Venkatesha, A.V.Shanbhag, G.M. Kulkarni, R.G.Alkhambkar (2008) Inhibition effects of some Schiff's bases on the corrosion of mild steel in hydrochloric acid solution, Corros.Sci., 50, 33563362.

[26] H.Ashassi-Sorkhabi, D. Seifzadeh , M.G.Hosseini, (2008) EN, EIS and polarization studies to evaluate the inhibition effect of $3 \mathrm{H}$-phenothiazin-3-one, 7dimethylamin on mild steel corrosion in $1 \mathrm{M} \mathrm{HCl}$ solution, Corros. Sci., 50, 3363-3370.

[27] A.Popova, M.Christov (2006) Evaluation of impedance measurements on mild steel corrosion in acid media in the presence of heterocyclic compounds, Corros. Sci., 48, 3208-3221.

[28] H.Ashassi-Sorkhabi, M.R.Majidi, K.Seyyedi (2004) Investigation of inhibition effect of some amino acids against steel corrosion in $\mathrm{HCl}$ solution, Appl. Surf. Sci., 225, 176-185.

[29] G. Moretti, G. Quartanone, A. Tassan, A. Zingales (1994) Inhibition of mild steel corrosion in $1 \mathrm{~N}$ sulphuric acid through indole ,Wekst. Korros., 45, 641-647.

[30] F.AMartin, F.A.C. Bataillon, J.Cousty (2008) In situAFM detection of pit onset location on a $304 \mathrm{~L}$ stainless steel, Corros. Sci., 50, 84-92.

[31] K.J.Jothi, K.Palanivelu (2013) Inhibition of mild steel corrosion in $1 \mathrm{~N}$ sulphuric acid through indole, Ceram. Int., 39, 7619- 7625.

[32] R.Pena-Alonso, F.Rubio, J.Rubio, J.L.Oteo (2007) Study of the hydrolysis and condensation of $\mathrm{Y}$ Aminopropyltriethoxysilane by FT-IR spectroscopy, J. Mater. Sci., 42, 595- 610.

[33] J. M. Hu, L. Liu, J. Q. Zhang, C. N. Cao (2007) Electrodeposition of silane films on aluminum alloys for corrosion protection, Prog. Org. Coat., 58, 265-271.

[34] H.Jiang, Z. Zheng, X. Wang (2008) Kinetic study of methyltriethoxysilane (MTES) hydrolysis by FTIR spectroscopy under different temperatures and solvents, Vib. Spectrosc., 46, 1-7. 


\section{IZVOD}

\section{EKSTRAKT BILJKE CALOTROPIS PROCERA KAO ZELENI INHIBITOR KOROZIJE ZA NERĐAJUĆI ČELIK No-304 U RASTVORU HLOROVODONIČNE KISELINE}

Uticaj ekstrakta Calotropis Procera (CP) kao inhibitora na koroziju nerđajućeg čelika No-304 (SS) u $2 \mathrm{M} \mathrm{HCl}$ proučavan je pomoću metoda: elektrohemijske impedansne spektroskopije (EIS), potentiodinamičke polarizacije (PP) $i$ elektrohemijske frekventne modulacije (EFM)) $i$ hemijskog gubitka težine $(G L)$ na $25^{\circ} \mathrm{C}$. Adsorpcija ekstrakta na površini nerđajućeg čelika No-304 SS je u skladu sa Langmirovom izotermom adsorpcije. Polarizacijske parcele otkrile su da dodavanje ekstrakta pomera katodnu i anodnu granu prema nižim strujama. Takvi pomaci ukazuju da CP ekstrakt deluje kao mešoviti inhibitor. Izračunati su i razmatrani termodinamički parametri procesa aktivacije $i$ adsorpcije. Površinska morfologija uzorka nerđajućeg čelika No-304 SS ocenjena je korišćenjem različitih tehnika.

Ključne reči: inhibicija korozije, nerđajući čelik No-304 SS, hlorovodonična kiselina, GL, PP, EIS, EFM.

Naučni rad

Rad primljen: 24.09.2017

Rad prihvaćen: 15.10.2017.

Rad je dostupan na sajtu: www.idk.org.rs/casopis

(C) 2017 Authors. Published by Inženjersko društvo za koroziju. This article is an open access article distributed under the terms and conditions of the Creative Commons Attribution 4.0 International license (https://creativecommons.org/licenses/by/4.0/) 